Ryszard Nowicki

Bydgoszcz

\title{
Projekt scenariusza filmowego na temat ochrony zbiorów bibliotecznych z 1946 roku
}

W powojennej Polsce do spraw szczególnej wagi należała ochrona zbiorów bibliotecznych. $\mathrm{W}$ wyniku doznanych ogromnych zniszczeń dóbr kultury, okresu II wojny światowej, władze państwowe uznały, że poniesione straty będzie można częściowo zrekompensować poprzez przejęcie, w oparciu o ustawę z 6 maja 1945 r., tzw. księgozbiorów opuszczonych i porzuconych ${ }^{1}$. Czynności zostały podjęte na terenie całego kraju, w tym na Pomorzu Gdańskim, gdzie przetrwały, często we fragmentach, szczególnie wartościowe księgozbiory historyczne. Jedną z wielu instytucji w kraju, gromadzącą cenne naukowe przekazy piśmiennicze, była Biblioteka Miejska w Gdańsku, kierowana przez Mariana Pelczara ${ }^{2}$. W Archiwum Zakładowym Biblioteki Gdańskiej Polskiej Akademii Na$\mathrm{uk}^{3}$ przetrwał wyjątkowy dokument, jedyny w swoim rodzaju, tj. projekt scenariusza zdjęć filmowych, związany z powojenną ochroną zbiorów bibliotecznych, prowadzoną przez gdańską Bibliotekę Miejskąa .

Tekst, pozbawiony informacji o autorze i datacji, zajmuje zaledwie jedną kartę maszynopisu. Składa się z dwóch części: I „Odzyskane

*Artykuł powstał w ramach projektu sfinansowanego ze środków Narodowego Centrum Nauki, przyznanych na podstawie decyzji nr DEC-2011/03/B/HS2/05446.

${ }^{1}$ Dziennik Ustaw 1945, nr 17, poz. 97: O majątkach opuszczonych i porzuconych.

${ }^{2}$ Marian Pelczar (1905-1983), historyk, dyrektor Biblioteki Miejskiej w Gdańsku (Biblioteki Gdańskiej Polskiej Akademii Nauk), autor ponad 80 rozpraw i studiów z dziejów Pomorza i Gdańska. Zob. Maria Babnis, Bibliografia prac Mariana Pelczara, „Rocznik Gdański”, 45:1985, z. 1, s. 21-31; Marian Pelczar, Biblioteka Miejska w Gdańsku, „Zapiski Towarzystwa Naukowego w Toruniu”, 13:1947, s. 40-54; tenże, Biblioteka Miejska w Gdańsku 1945-1953, „Rocznik Gdański”, 13:1954, s. 159-180.

${ }^{3}$ Biblioteka Miejska w Gdańsku w 1955 r. otrzymała nazwę: Biblioteka Gdańska Polskiej Akademii Nauk.

${ }^{4}$ Biblioteka Gdańska Polskiej Akademii Nauk, Archiwum Zakładowe (dalej cyt. AZBG PAN), Organizacja Biblioteki Miejskiej w Gdańsku 1945-1947, Poszyt 2, k. 43 Projekt scenariusza [z]djęć filmowych w Bibliotece Miejskiej w Gdańsku. 
skarby” i II „Biblioteka pracuje”. W pierwszej nawiązano do czynności związanych z ratowaniem i transportowaniem dzieł pisanych z Malborka do Gdańska, a druga stanowiła okazję do przedstawienia rezultatów pracy Biblioteki Miejskiej i zaprezentowania szczególnie wartościowych zbiorów, wśród których znajdowały się dzieła, m.in.: Jana Heweliusza, Gotfryda Lenghnicha, Krzysztofa Mrongowiusza oraz księgozbiór Jana Uphagena. Projekt scenariusza powstał w dużym pośpiechu. Świadczą o tym liczne usterki (uzupełnienia w nawiasach kwadratowych pochodza od wydawcy).

Kto napisał projekt scenariusza? Przypuszczam, że za autora należy uznać dyrektora Biblioteki Miejskiej Mariana Pelczara. Był on członkiem Gdańskiej Grupy Operacyjnej Ministerstwa Oświaty, na czele której stał Stanisław Turski. W mieście znajdowały się niezwykle wartościowe zbiory biblioteczne i archiwalne, wymagające natychmiastowej ochrony. Marian Pelczar rozpoczął prace związane z zabezpieczeniem księgozbiorów w Oliwie ${ }^{5}$, a od 9 kwietnia 1945 r. dzieł Biblioteki Miejskiej w Gdańsku' ${ }^{6}$. Podczas pierwszego obejścia obiektu, stwierdził poważne uszkodzenia budynku, $\mathrm{w}$ tym powstałe $\mathrm{w}$ wyniku ostrzału artyleryjskiego. Zwrócił uwagę na braki w zasobie księgozbioru oraz fatalny stan techniczny Biblioteki, w której zostały wybite wszystkie szyby, wyłamane drzwi oraz zerwane dachówki. Jego spostrzeżenia bez wattpienia zostały uwzględnione w piśmie, opatrzonym pieczęcią $\mathrm{z}$ napisem: Ministerstwo Oświaty/Delegatura na miasto Gdańsk, sporządzonym w Gdańsku-Oliwie 10 kwietnia 1945 r., a podpisanym przez Stanisława Turskiego ${ }^{7}$. List,

${ }^{5}$ Marian Pelczar wyjechał do Gdańska 23 lutego 1945 r., by, z polecenia ministra oświaty Stanisława Skrzeszewskiego, zająć się ochroną zbiorów bibliotecznych. Do miasta, w warunkach trwającej jeszcze wojny, dotarł 5 kwietnia 1945 r. Dzień później przystapił do zabezpieczenia Biblioteki Katedralnej w Oliwie. 9 kwietnia tego roku, postanowieniem Zarządu Miejskiego w Gdańsku, objął kierownictwo Biblioteki Miejskiej. Przez kilka pierwszych miesięcy pełnił funkcję naczelnika Wydziału Kultury i Nauki Zarządu Miejskiego w Gdańsku - AZBG PAN, Akta osobowe - Pelczar Marian, sygn. A wyk. 16/1 32, k. 56 - Marian Pelczar, Życiorys, Gdańsk, 1 października 1970 r. 30 kwietnia 1945 r. Ministerstwo Oświaty upoważniło Mariana Pelczara do objęcia kierownictwa Biblioteki Miejskiej oraz prowadzenia wszelkich prac związanych z zabezpieczeniem i porządkowaniem księgozbiorów znajdujących się na terenie Gdańska. Pełnomocnictwo zostało udzielone na czas nieokreślony.

${ }^{6}$ AZBG PAN, Sprawozdanie z działalności Biblioteki Miejskiej w Gdańsku 19451948, Poszyt BM5, k. 5 - [Marian Pelczar], Sprawozdanie z prac nad zabezpieczeniem i uporządkowaniem Biblioteki Miejskiej za czas od 9 kwietnia do 13 czerwca $1945 \mathrm{r}$. Zob. Marian Pelczar, Wspomnienia z pierwszego roku pracy w Bibliotece Gdańskiej 1945-1946, „Libri Gedanenses. Rocznik Biblioteki Gdańskiej Polskiej Akademii Nauk” 1967, R. 1, s. 7-34.

${ }^{7}$ Być może autorem treści dokumentu, podpisanego przez Stanisława Turskiego, był Marian Pelczar. 
skierowany do Wojewódzkiej Komendy Milicji Obywatelskiej w Gdańsku, posiadał następującą treść:

Gdańska Grupa Operacyjna Ministerstwa Oświaty, mając w zakresie swych zadań polecone również zabezpieczenie i zorganizowanie wszelkich zbiorów archiwalnych i bibliotecznych na ternie Gdańska[,] przeprowadziła między innymi zbadanie budynków i zbiorów b[yłego] Archiwum Państwowego, oraz b[yłej] Biblioteki Miejskiej w Gdańsku.

Pracę tę przeprowadził delegowany specjalnie dla działu archiwów i bibliotek członek grupy ob. dr Marian Pelczar. W wyniku przeprowadzonego przez niego zbadania okazało się koniecznym i niezbędnym[,] przed przystapieniem do normalnej pracy inwentaryzacyjno-naukowej[,] natychmiastowe oczyszczenie oraz zabezpieczenie budynków i zbiorów archiwalnych i bibliotecznych.

W tym celu prosimy o wydanie odpowiednich zarządzeń - a mianowicie:

1) usunięcie przebywających jeszcze chwilowo w budynku archiwum uchodźców,

2) usunięcie pozostających jeszcze w budynkach (specjalnie w klatce schodowej oraz pokoju pierwszego piętra budynku biblioteki) zwłok,

3) usunięcie ewentualnie się jeszcze znajdującego w budynkach materiatu wojennego (zapalniki, granaty, naboje itp.),

4) dostarczenie odpowiednich sił roboczych do natychmiastowego uprzątnięcia budynku, przeniesienia zbiorów archiwalnych z rozbitej części budynku archiwalnego do gmachu biblioteki, oraz do przeprowadzenia zaszalowania deskami, względnie zabezpieczenia okien parteru budynku biblioteki. Przewidziana ilość osób do tych prac wynosi 30 osób przez 6 dni,

5) zabezpieczenie zbiorów przez wystawienie stałego posterunku Milicji, aż do chwili wstawienia szyb, względnie zaszalowania okien parteru budynku biblioteki, oraz aż do czasu należytego zabezpieczenia i zamknięcia bramy wejściowej.

Ze względu na bardzo wielką wartość narodową i naukową gdańskich zbiorów archiwalnych i bibliotecznych wskazanym jest natychmiastowe przeprowadzenie powyższych prac.

Nie bacząc na liczne trudności Marian Pelczar z energią przystapił do naprawy szkód i zabezpieczenia zbiorów Biblioteki Miejskiej oraz dawnego archiwum w Gdańsku ${ }^{8}$ Ze zniszczonego niemalże całkowicie bu-

${ }^{8}$ Pracownicy Biblioteki Miejskiej od kwietnia 1945 r. prowadzili także zabezpieczanie oliwskiej Biblioteki Katedralnej i zbiórkę książek poniemieckich na terenie Oliwy. Sytuacja ta doprowadziła do powstania w czerwcu 1945 r. Ekspozytury Gdańskiej Biblioteki Miejskiej w Oliwie, która współpracowała z utworzoną przy Kuratorium Okrę- 
dynku archiwum oraz ratusza przeniósł resztki archiwaliów, które przetrwały w piwnicach, tj.: akta klasztorów z XIV-XVIII w., dziewiętnastowieczne akta hipoteczne Zarządu Miejskiego i szkolne Gdańska, 8500 dokumentów mieszczańskich z XVII-XIX w., 40 skrzyń z korespondencją dotyczącą Gdańska z XVIII w., dokumenty kościołów gdańskich, pozostałości archiwaliów miejskich miast pomorskich (Kościerzyny, Chojnic, Chełmna, Gniewa, Pucka i innych) oraz część biblioteki podręcznej byłego archiwum ${ }^{9}$. Pomimo trudności lokalowych do czerwca $1945 \mathrm{r}$. w Bibliotece Miejskiej przesortowano około 35000 tomów z dawnych bibliotek polskich, a także innych, z terenu Wolnego Miasta Gdańska. Materiały pochodziły m.in. z bibliotek: Polskiego Gimnazjum w Gdańsku, Polskiej Szkoły Średniej, Polskiej Rady Kultury, Polskiej Kasy Rządowej, Wysokiego Komisarza Ligi Narodów, licznych prywatnych polskich, loży masońskiej „Eugenia” oraz Sierakowskich z Waplewa. Odnaleziony i uporządkowany został katalog główny Biblioteki Miejskiej, składający się z 206 tomów ${ }^{10}$. Marian Pelczar stwierdził wówczas brak 14 tomów, w tym pięciu tomów obejmujących dział gdański oraz czterech tomów bibliografii gdańszczan ${ }^{11}$. Odzyskał również część zbiorów bibliotecznych wywiezionych z Biblioteki Miejskiej do Malborka, tj. fragment działu „Uph"12 (Uphagen).

Marian Pelczar rozpoczął poszukiwania brakujących dzieł, przede wszystkim pochodzących z księgozbioru Biblioteki Miejskiej, z której Niemcy podczas wojny wywieźli kilkadziesiąt tysięcy najcenniejszych rękopisów, inkunabułów oraz starych druków. Zostały one umieszczone w Malborku, Pelplinie i piwnicach ratusza staromiejskiego w Gdańsku. Część z nich, zwłaszcza zgromadzonych w malborskim zamku, pod koniec wojny uległa zniszczeniu. Brak środków transportu stanowił poważną przeszkodę w rytmicznym zwożeniu ocalonych tomów.

Pod koniec kwietnia 1945 r. Ministerstwo Oświaty upoważniło Mariana Pelczara do zabezpieczenia księgozbiorów na terenie samego Gdańska. Wielokrotnie dostawał także zgodę Ministerstwa oraz Zarządu Miejskiego w Gdańsku na wyjazdy w teren i zwożenie materiałów bibliotecznych

gu Szkolnego Gdańskiego Komisją Wojewódzką Opieki nad Książką - zob. Ryszard Nowicki, Działalność Aleksandra Birkenmajera na rzecz powojennej ochrony zbiorów bibliotecznych. Ziemie zachodniej i pólnocnej Polski w latach 1945-1947, Poznań 2006, s. $72-77$.

9 AZBG PAN, Sprawozdanie z działalności Biblioteki Miejskiej w Gdańsku 19451948, Poszyt BM5, k. 6 - [Marian Pelczar], Sprawozdanie z prac nad zabezpieczeniem i uporządkowaniem Biblioteki Miejskiej za czas od 9 kwietnia do 13 czerwca 1945 r.

${ }^{10}$ Tamże.

11 Tamże.

${ }^{12}$ Tamże, k. 7. 
i archiwalnych. Najbardziej wytrwale poszukiwał jednak dzieł pochodzących z Biblioteki Miejskiej ${ }^{13}$. Zasięg jego aktywności terytorialnej uległ powiększeniu 12 lutego 1947 r., kiedy otrzymał upoważnienie podpisane przez Naczelnego Dyrektora Bibliotek Józefa Grycza, do zabezpieczenia zbiorów bibliotecznych na terenie województw gdańskiego, olsztyńskiego i dwóch powiatów: bytowskiego i słupskiego, należących do województwa zachodniopomorskiego. Sytuacja ta wynikała z faktu utworzenia 1 lutego 1947 r. Zbiornicy Księgozbiorów Zabezpieczonych w Gdańsku.

Doświadczenie zdobyte podczas wyjazdów w teren, transportowania dzieł, a następnie ich segregacji i porządkowania w kierowanej przez siebie placówce, mogły stanowić impuls do skreślenia scenariusza filmowego przez dyrektora Biblioteki Miejskiej. Dodatkowy argument, przemawiający za autorstwem Mariana Pelczara, stanowi fakt aktywnej popularyzacji zbiorów bibliotecznych, historii Gdańska i Pomorza Gdańskiego w audycjach emitowanych przez rozgłośnię Polskiego Radia Gdańsk. Od 14 grudnia 1945 r. do 14 października 1946 r. uczestniczył on w 39 audycjach radiowych. Jego wypowiedzi radiowe ukazały się drukiem w publikacji zatytułowanej Mariana Pelczara wizja Gdańska (Audycje radiowe z lat 1945-1946), wydanej przez Bibliotekę Gdańską Polskiej Akademii Nauk w 2005 r. $^{14}$. Pierwsza z nich nosiła tytuł „Biblioteka Miejska w Gdańsku i jej dzieje".

Kiedy powstał scenariusz filmowy? Najprawdopodobniej został napisany w 1946 r. Doskonałą okazją mogło być uroczyste otwarcie Biblioteki, połączone z rocznica 350-lecia placówki, którą obchodzono 22 czerwca $1946 \mathrm{r}$. Tego dnia uporządkowane zbiory biblioteczne zostały oddane do użytku publicznego. Otwarcie Biblioteki i 350-lecie jej istnienia, stanowiły doskonałą okazję do promocji i reklamy, która skwapliwie wykorzystał dyrektor. Z uzasadnioną satysfakcja napisał: „Uroczystość ta dała okazję do zapoznania się ze zbiorami Biblioteki licznym bibliotekarzom i przedstawicielom świata nauki z całej Polski, oraz spopularyzowania Biblioteki na terenie Gdańska i Wybrzeża. Z okazji otwarcia Biblioteki miał miejsce liczny zjazd delegatów i przedstawicieli władz centralnych i miejscowych, uniwersytetów, in-

${ }^{13}$ Do Biblioteki Miejskiej w Gdańsku był zwożone także tomy, m.in. z Warszawy, Torunia czy Grudziądza. Sytuacja ta wynikała z faktu wcześniejszego przydziału woluminów przez Ministerstwo Oświaty innym instytucjom (np. trafiły one do Muzeum Wojska Polskiego w Warszawie, Biblioteki Uniwersyteckiej w Toruniu, Biblioteki Uniwersyteckiej w Warszawie, Biblioteki Narodowej).

${ }^{14}$ Publikacja ta zawiera także dwa teksty audycji wygłoszonych w 1952 r. i w 1955 r. Marian Pelczar publikował artykuły na łamach czasopism naukowych oraz gazet, m.in. „Dziennika Bałtyckiego”, „Ziemi Pomorskiej”. 
stytutów i bibliotek z całej Polski. Uczestników Zjazdu ${ }^{15}$ spoza Gdańska było 106. Szereg przemówień wygłoszonych w czasie trwania Zajazdu, liczne pisma[,] jakie Biblioteka $\mathrm{z}$ tej okazji otrzymała, oraz wiele artykułów prasowych sprawozdawczych stwierdzały jednogłośnie bardzo wielką naukową i społeczną wartość zbiorów Biblioteki. W związku z uroczystością otwarcia Biblioteki urządzono wystawę najcenniejszych zbiorów Biblioteki z działu rękopisów i starodruków, powtórzoną następnie w lipcu br. z okazji Święta Morza. Ministerstwo Oświaty uznało Bibliotekę Miejską w Gdańsku za Bibliotekę Naukową ${ }^{16}$ w rozumieniu wartości jej zbiorów, oraz przyznało jej prawa Biblioteki Regionalnej dla województwa gdańskiego, polecając jej gromadzenie egzemplarza obowiązkowego z terenu województwa i rozsyłanie go w ramach ogólnopolskiej akcji E.O." ${ }^{17}$.

Wartość zgromadzonego zbioru podkreślał fakt, iż Ministerstwo Oświaty przyznało Bibliotece Miejskiej liczne zabezpieczone księgozbiory naukowe poniemieckiej proweniencji. Wśród nich znajdowały się m.in. cenne stare druki Bilbioteki Zappio-Johannitana ${ }^{18}$ czy zbiory biblioteczne rodziny von der Goltz. Do końca 1946 r. księgozbiór naukowy Biblioteki Miejskiej liczył ponad 250000 tomów, a bogaty zbiór starych druków ponad 50000 tomów $^{19}$. W omawianym okresie gdańska Biblioteka Miejska była największą książnicą naukową na terenie Polski północno-zachodniej ${ }^{20}$. Na początku lutego $1947 \mathrm{r}$. Ministerstwo Oświaty zorganizowało przy Bibliotece Zbiornicę Księgozbiorów Zabezpieczonych $^{21}$, jedną z siedmiu utworzonych na terenie kraju. Decyzja ta spowodowała dodatkowe możliwości zrekompensowania strat okresu II wojny światowej i powiększenia księgozbioru.

${ }^{15}$ Uroczystość otwarcia Biblioteki połączona była z nieoficjalnym pierwszym powojennym zjazdem bibliotekarzy polskich w Gdańsku.

${ }^{16}$ Pisownia zgodna ze źródłem.

${ }_{17}$ AZBG PAN, Sprawozdanie z działalności Biblioteki Miejskiej w Gdańsku 19451948, Poszyt BM5, k. 50 - Marian Pelczar, Sprawozdanie z działalności Biblioteki Miejskiej w Gdańsku za okres od dnia 1 kwietnia 1946 do 31 grudnia 1946.

${ }_{18}$ Biblioteka przy kościele św. Jana w Gdańsku liczyła kilka tysięcy dzieł o treści teologiczno-filozoficznej.

19 AZBG PAN, Sprawozdanie z działalności Biblioteki Miejskiej w Gdańsku 19451948, Poszyt BM5, k. 51 - Marian Pelczar, Sprawozdanie z działalności Biblioteki Miejskiej w Gdańsku za okres od dnia 1 kwietnia 1946 do 31 grudnia 1946.

${ }^{20}$ Biblioteka Uniwersytecka w Toruniu powstała w 1945 r. Fundament własnego zbioru naukowego tworzyła z księgozbiorów zabezpieczonych, przede wszystkim poniemieckiej proweniencji.

${ }^{21}$ Pierwszym kierownikiem Zbiornicy Księgozbiorów Zabezpieczonych w Gdańsku został Marian Pelczar, a następnie obowiązki przejęła Helena Kalewska. Zbiornica zakończyła działalność na początku 1950 r. W trakcie jej likwidacji część zbiorów została przekazana do Zbiornicy Księgozbiorów Zabezpieczonych w Katowicach. 
Ze sprawozdania z działalności Biblioteki Miejskiej w Gdańsku za okres od 1 kwietnia 1946 r. do 31 grudnia 1946 r., wynika, że działania rewindykacyjne, związane z odszukaniem i zwiezieniem zbiorów Biblioteki Miejskiej, były w zasadzie zakończone ${ }^{22}$. Jednak nie zdołano przetransportować wszystkich książek, stanowiących własność Biblioteki, w tym z Malborka, które to miasto nieprzypadkowo zostało wymienione w scenariuszu. Od początku kwietnia do końca grudnia 1946 r., w trakcie dziewięciu wypraw, zwieziono około 35 ton książek. Wśród nich przeważały cenne stare druki i rękopisy. Wobec docierających sygnałów z terenu o odnalezieniu kolejnych woluminów, czynności te były kontynuowane w następnym roku. Mimo to, nie zdołano odszukać wszystkich pozycji, a ubytki w cenniejszych partiach księgozbiorów pozostawały nadal dotkliwe. W dziale rękopisów brakowało około 2500 pozycji, inkunabułów 475 tomów, co najmniej 3000 rycin, znacznej ilości map i ekslibrisów, a także około 15 tys. tomów innych książek. Liczby te były jedynie szacunkowe ${ }^{23}$.

Na podstawie analizy zebranego materiału źródłowego można przypuszczać, że scenariusz powstał w 1946 r., a jego autorem był Marian Pelczar. Dyrektor przystapił z dużą determinacją do ochrony zbiorów bibliotecznych i ratowania dzieł pisanych. Zajmował się popularyzacją zbiorów Biblioteki Miejskiej, wykorzystując w tym celu m.in. prasę oraz radio. Autor niniejszych słów nie zdołał ustalić czy w oparciu o skreślony scenariusz powstał film dokumentalny ${ }^{24}$. Należy stwierdzić, iż odszukany dokument jest szczególnie interesującym przekazem źródłowym, wskazującym na chęć utrwalenia na taśmie filmowej czynności, służących odbudowie bibliotek i bibliotekarstwa oraz podkreślenia wagi i znaczenia gromadzonych wyjątkowo cennych księgozbiorów historycznych przez Bibliotekę Miejską w Gdańsku, których wartość naukowa posiada wymiar regionalny, ogólnokrajowy oraz europejski.

${ }^{22}$ AZBG PAN, Sprawozdanie z działalności Biblioteki Miejskiej w Gdańsku 19451948, Poszyt BM5, k. 50 - Marian Pelczar, Sprawozdanie z działalności Biblioteki Miejskiej w Gdańsku za okres od dnia 1 kwietnia 1946 do 31 grudnia 1946.

${ }^{23}$ Tamże, k. 53-54.

${ }^{24}$ Nie został podany czas trwania przyszłego filmu. Przypuszczalnie mógł być planowany najwyżej na około 10-15 minut (podobnie, jak emitowane audycje radiowe Mariana Pelczara). Wytwórnia Filmów Dokumentalnych niezrealizowała żadnego monotematycznego filmu, który w całości byłby poświęcony powojennej ochronie zabytków bibliotecznych. Autor dziękuje za informację kierownikowi Archiwum Filmowego 1 Chełmska Filmoteki Narodowej Annie Lewandowicz. 


\section{Projekt scenariusza zdjęć filmowych w Bibliotece Miejskiej w Gdańsku [Gdańsk, 1946 r.]}

Źródło: AZBG PAN, Organizacja Biblioteki Miejskiej w Gdańsku 1945-1947, Poszyt 2, k. 43.

\section{Część I [.]: „Odzyskane zbiory”}

Godzina 7-ma wieczorem. Kilku wyznaczonych pracowników oc[ze]kuje na przyjazd samochodu ciężarowego, który pojechał teg[o] dnia o świcie celem przywiezienia ocalonych, najcenniejszy[ch] zbiorów Biblioteki Miejskiej w Gdańsku, wywiezionych przez niemców [! $]^{25}$ do Malborka. Oczekiwanie się przedłuża. Wobec tego korzystamy z wolnego czasu i oglądamy budynek biblioteki. Widać jeszcze ślady zniszczeń choć są już wszystkie szyby ${ }^{26}$, dach naprawiony i załatana wyrwa w murze. Również odnowione jest wnętrze. Przechodzimy do magazynu. Oglądamy bogaty księgozbiór. W tym dają znać, że oczekiwany samochód nadjechał. Wychodzimy przed budynek. Nadjeżdża wóz pełny książek i skrzyń, na nim uczepieni siedzą pracownicy Biblioteki, są to w znacznej mierze tzw. na-

${ }^{25}$ Pisownia zgodna $\mathrm{z}$ oryginałem. Tuż po wojnie $\mathrm{w}$ dokumentach rękopiśmiennych oraz materiałach publikowany niejednokrotnie celowo nie stosowano zasad ortograficznych, dotyczących pisowni z dużej litery. W ten sposób starano się wyrazić pogardę dla okupanta za ogrom krzywd doznanych podczas wojny.

${ }^{26}$ Przez długi okres budynek Biblioteki Miejskiej pozbawiony był szyb. Czynione przez Mariana Pelczara starania o ich pozyskanie nie przynosiły pożądanego rezultatu. Dyrektor napisał: „W magazynie biblioteki nie można przystapić do pracy układania książek ze względu na brak szyb, skutkiem czego wiatr ustawicznie zrzuca z półek lżejsze książki, zaśmieca zbiory kurzem[,] a zacinający deszcz uniemożliwia stawianie książek blisko okien. Kilkakrotne interwencje osobiste dyrektora biblioteki w Wydziale Budowlanym Prezydium Zarządu Miejskiego i u innych władz pozostawały dotychczas[,] z powodu braku ludzi w Gdańsku[,] bez skutku. Częściowe zabezpieczenie okien drobnymi ilościami dykty i tektury, jakie prywatnie zdobyto przy pomocy kilku dorywczo zaangażowanych robotników[,] są drobiazgiem w porównaniu z całością zapotrzebowania" - AZBG PAN, Sprawozdanie z działalności Biblioteki Miejskiej w Gdańsku 1945-1948, Poszyt BM 5, k. 7 - [Marian Pelczar], Sprawozdanie z prac nad zabezpieczeniem i uporządkowaniem Biblioteki Miejskiej w Gdańsku za czas od 9 kwietnia do 13 czerwca 1945 r. Ostatecznie Marianowi Pelczarowi, po ponad półrocznych bezskutecznych zabiegach, w wyniku „daru” Ministerstwa Oświaty, udało się pozyskać potrzebny materiał, którego w powojennych warunkach dotkliwie brakowało w kraju. Świadczą o tym jego podziękowania, wyrażone w liście z 12 listopada 1945 r., za przekazane przez Ministerstwo Oświaty szyby, - AZBG PAN, Korespondencja z ministerstwami 1945-1946, Poszyt 8, k. 10 - Marian Pelczar do Ministerstwa Oświaty w Warszawie, Gdańsk 12 listopada 1945 r. Zatem można stwierdzić, na podstawie wzmianki o dostarczeniu materiału wystarczającego do oszklenia wszystkich okien w Bibliotece, że scenariusz powstał po 12 listopada $1945 \mathrm{r}$. 
ukowcy, bo odzyskane zbiory, to przede wszystkim najcenniejsze rękopisy i starodruki wraz z tzw. inkunabułami, pierwszymi drukami XV wieku. Samochód podjeżdża pod bramę. Brama otwiera się momentalnie, spuszczono klapę samochodu i bez słowa polecenia bibliotekarze tworzą ,łańcuszek"[,] i poszczególne tomy podawane pieczołowicie z rąk do rąk[,] wędrują z wozu do Biblioteki. Widać wśród nich stare kosztowne oprawy ${ }^{27}$, są olbrzymie tomiska, które ledwie jedna osoba może podnieść.

Idziemy za [,,]łańcuszkiem["]. Przywiezione tomy składa się na razie na boku, następnego dnia zostaną one przesortowane i włączone do magazynu.

\section{Część II: „Biblioteka pracuje”}

Najważniejsza praca to ułożenie księgozbioru celem udostępnienia go [w] każdej chwili czytelnikowi. Jesteśmy znowu w magazynie Biblioteki. Układa się tu książki według odpowiedniego systemu ${ }^{28}$. Praca ta[,] po zniszczeniu Biblioteki podczas działań wojennych[,] wymagała dużego wysiłku fizycznego przy przerzucaniu całych partii książek z parteru na VI piętro (winda została rozbita). Przebiegamy przez 6 pięter magazynu aż na strych, gdzie znajdują się zabezpieczone i jeszcze nieskatalogowane księgozbiory opuszczone.

Zainteresowanie dla książek wzrasta. W dziale rękopisów i starodruków oglądamy najcenniejsze polonica ${ }^{29}$. Przed oczyma przesuwa się kilka egzemplarzy „,białych kruków”. Biblioteka Gdańska powstała z szeregu prywatnych bibliotek gdańskich patrycjuszy. Sięgamy wstecz do jej początków i jej przypadkowego ,założyciela” włoskiego markiza d'Oria ${ }^{30}$. Oglądamy jego portret ${ }^{31}$ i katalog jego biblioteki. Oglądamy dzieła Heve-

${ }^{27}$ W Bibliotece przechowywane są cenne oprawy, w tym inkunabułów, wykonane w warsztatach wybitnych gdańskich introligatorów. Autor scenariusza słusznie uznał, że zabytkowe i artystycznie wykonane oprawy, chroniące dzieła, mogą wzbudzić ciekawość przyszłego widza.

28 Zapewne według Instrukcji Ministerstwa Oświaty z dnia 25 stycznia1946 r. W sprawie postępowania z księgozbiorami zabezpieczonymi, opracowanej przez Józefa Grycza.

${ }^{29} \mathrm{Na}$ terenie Pomorza Gdańskiego, w przeciwieństwie do Pomorza Zachodniego, występowały licznie polonika.

${ }^{30} \mathrm{~W}$ scenariuszu nawiązano do początków Biblioteki Miejskiej. Biblioteka Senatus Gedanensis została uroczyście otwarta 22 czerwca 1596 r. Podstawą stał się księgozbiór włoskiego podróżnika markiza Johannesa Bernardinusa Bonifaciusa d'Oria, którego statek z książkami zatonął u ujścia Wisły 25 sierpnia 1591 r. Zdołano uratować większą część księgozbioru, tj. ponad 1300 dzieł. Ocalone tomy stały się podstawą Biblioteki Rady Miasta Gdańska.

${ }^{31}$ Portret, zdobiący czytelnię naukowa, namalował A. Moeller w 1597 r. Przedstawia on humanistę i bibliofila Johannesa d'Oria na łożu śmierci. 
liusza $^{32}$ dedykowane Janowi Sobieskiemu ${ }^{33}$. Lengnich ${ }^{34}$ i jego „Polnische Bibliothek"[,] to dalszy ciekawy szczegół patriotyzmu polskiego gdańskich mieszczan. Ciekawa postać rajcy gdańskiego Uphagena ${ }^{35}$ i wspaniałej $^{36}$ jego $15000[-t y s i e ̨ c z] n e j ~ b i b l i o t e k i$, to też rzec[z] godna uwagi. A wreszcie czysto niemal polska biblioteka Krzysztofa Celestyna Mrongowiusza $^{37}[$,] ostatniego lektora języka polskiego w Gdańskim Gimnazjum Akademickim.

Książki jednak nie stoją bezużytecznie. Rzut oka na wypożyczalnię i czytelnię[,] jako pracownie polskich uczonych w polskiej bibliotece[,] w polskim Gdańsku ${ }^{38}$.

\section{Streszczenie}

\section{Projekt scenariusza filmowego powojennej ochrony zbiorów bibliotecznych}

W zbiorach Biblioteki Gdańskiej Polskiej Akademii Nauk przechowywane jest wyjątkowe źródło, tj. projekt scenariusza filmowego powojennej ochronnych zbiorów bibliotecznych, prowadzonej przez Bibliotekę Miejską w Gdańsku. Dokument podzielony został na dwie części. W pierwszej nawiązano do transportowania księgozbiorów proweniencji gdańskiej, wywiezionych podczas wojny przez Niemców, z Malborka do Gdańska W drugiej części przedstawiono osiagnięcia pracy Biblioteki Miejskiej. Projekt scenariusza pozbawiony jest datacji i informacji o autorze. Na podstawie analizy źródeł stwierdzono, że autorem tekstu był dyrektor Biblioteki Miejskiej w Gdańsku Marian Pelczar, a tekst powstał w 1946 r. Doskonałą okazją do skreślenia scenariusza stało się oddanie

${ }^{32}$ Do unikatowych zachowanych starych druków należą kolorowane dzieła Jana Heweliusza (1611-1687), gdańszczanina i astronoma.

${ }^{33}$ W 1679 r. ukazała się druga część dzieła Jana Heweliusza Machina coelestis, dedykowana Janowi III Sobieskiemu, zawierająca obserwacje astronomiczne.

34 Gotfryd Lengnich (1689-1774), prawnik i historyk, nauczyciel gimnazjum w Gdańsku. Badał dzieje Prus i prawo polskie. Wydawał w Gdańsku, w latach 17181719, pierwsze na ziemiach polskich czasopismo naukowe historyczne, o charakterze informacyjno-bibliograficznym, ,Polnische Bibliothek”.

35 Jan Uphagen (1731-1802), zasłużony dla kultury Gdańska bibliofil. Zgromadził wyjątkowo cenny księgozbiór, obfitujący w polonica, liczący ok.15000 tomów. W 1879 r. został on włączony do zbiorów Biblioteki Miejskiej w Gdańsku.

${ }^{36} \mathrm{~W}$ źródle jest: wspaniale.

${ }^{37}$ Krzysztof Celestyn Mrongowiusz (1764-1855), pisarz i thumacz. Popularyzator języka polskiego. Obrońca polskości na Warmii i Mazurach. Pracował w Gdańskim Gimnazjum Akademickim.

${ }^{38}$ Autor pragnął w ten sposób podkreślić polskość Gdańska, które to miasto, podczas przejęcia w 1945 r. przez polską administrację z rąk wojskowych władz sowieckich, nie miało zagwarantowanych uregulowań prawno-międzynarodowych - por. Mariana Pelczara wizja Gdańska (Audycje radiowe z lat 1945-1946), Gdańsk 2005, s. 6. 
do publicznego użytku Biblioteki Miejskiej w Gdańsku 22 czerwca 1946 r. Uroczystość ta połączono była z rocznicą 350-lecia istnienia instytucji naukowej, w której zgromadzone zostały niezwykle wartościowe materiały piśmiennicze, w tym dzieła gdańskiego astronoma Jana Heweliusza, Krzysztofa Mrongowiusza, Gotfryda Lengnicha oraz cenny księgozbiór Jana Uphagena. Odnaleziony dokument jest szczególnie interesującym przekazem źródłowym, wskazującym na chęć utrwalenia, w formie filmu dokumentalnego, czynności służących odbudowie bibliotek i bibliotekarstwa oraz podkreślenia znaczenia gromadzonych wyjątkowo cennych księgozbiorów historycznych przez Bibliotekę Miejską w Gdańsku, których wartość naukowa posiada wymiar europejski.

\section{Summary}

\section{An Idea of a Film Dedicated to Book Preservation, 1946}

Among the materials kept at the Gdańsk Library of the Polish Academy of Sciences, one finds an exceptional piece of evidence - a plan for a film documentary dedicated to post-World War 2 efforts to preserve library collections, conducted by the personnel of the aforementioned library. This plan is divided into two parts. Part one portraits the works on transporting the collections, hidden by the Germans during the war in Malbork, back to Gdańsk. Part two shows the functioning of the reconstructed library. This draft is devoid of information concerning its author and dating. An analysis of the plan and its sources demonstrated that it must have been drawn up in 1946, by Marian Pelczar, the director of the library. It seems that the best moment for such ideas was 22 June 1946, when the library was officially reopened to the public after the war. That celebrated moment coincided with the $350^{\text {th }}$ anniversary of the establishment of the institution, which housed important materials, including the works of the Gdańsk astronomer Johannes Hevelius, Krzysztof Mrongowiusz, Gotffried Lengnich, or the valuable book collection of Johann Uphagen.

The plan for the film is particularly interesting, because it shows the aspirations to record in the form of a film documentary the efforts of the library milieu in reconstructing the Gdańsk Library, and the libraries in the region in general, and to emphasize the importance of the Gdańsk collections, the cultural significance of which are of European rank. 